Article

\title{
Short-Term Effects of Sewage Sludge Compost Amendment on Semiarid Soil
}

\author{
Maddalena Curci ${ }^{1,+}$, Anna Lavecchia ${ }^{2,+}$, Giovanna Cucci ${ }^{3}$, Giovanni Lacolla ${ }^{3}$, Ugo De Corato ${ }^{4}$ \\ and Carmine Crecchio ${ }^{1, *(\mathbb{D})}$ \\ 1 Department of Soil, Plant and Food Science (DiSSPA), University of Bari Aldo Moro, Via Amendola 165/A, \\ 70126 Bari, Italy; maddalena.curci@uniba.it \\ 2 Institute of Biomembranes, Bioenergetics and Molecular Biotechnologies-National Council of \\ Research (IBIOM-CNR), Via Giovanni Amendola, 122/0, 70126 Bari, Italy; a.lavecchia@ibiom.cnr.it \\ 3 Department of Agricultural and Environmental Science (DiSAAT), University of Bari Aldo Moro, \\ Via Amendola 165/A, 70126 Bari, Italy; giovanna.cucci@uniba.it (G.C.); giovanni.lacolla@uniba.it (G.L.) \\ 4 Department of Bioenergy, Biorefinery and Green Chemistry-Italian National Agency for the New \\ Technologies, Energy and Sustainable Economic Development (DTE-BBC-BIC-ENEA), Territorial Office of \\ Bari-Via Giulio Petroni 15/F, 70124 Bari, Italy; ugo.decorato@enea.it \\ * Correspondence: carmine.crecchio@uniba.it; Tel.: +39-080-5442854 \\ + These authors contributed equally to this work.
}

Received: 10 June 2020; Accepted: 31 July 2020; Published: 5 August 2020

Abstract: The adoption of sewage sludge as an agricultural management strategy to improve soil properties and crop production is attracting great interest. Despite many positive effects on soil inorganic and organic components reported for different soil types, little information is available on sewage sludge application on Mediterranean soils, as well as on its use at different dose rates. The objectives of the present research was to evaluate, through an integrated approach, the effects of sewage sludge compost from urban wastewater on physicochemical, hydrological, biochemical parameters, and microbiota composition in soil pots under a three-year crop rotation system. Four different doses of sewage sludge compost $(\mathrm{C} 3, \mathrm{C} 6, \mathrm{C} 9, \mathrm{C} 12)$ from municipal wastewater and a dose of them in combination with mineral fertilizer (C6N) were used. We have used 3-6-9-12 Mg/ha of sewage sludge compost for the treatments C3, C6, C9 and C12, respectively, and $6 \mathrm{Mg} / \mathrm{ha}$ of sewage sludge compost in combination with $60 \mathrm{~kg} / \mathrm{ha}$ of ammonium nitrate for the treatment C6N.The effects were compared to non-fertilized (C0) and mineral fertilized (Min) sets of controls. The electrical conductivity, soil $\mathrm{pH}$, stability of soil aggregates, percent of moisture of the dry soil both at the field capacity and at the wilting point, available $\mathrm{P}$, and exchangeable $\mathrm{K}$ were all positively affected by increasing the amounts of composted sludge. The organic carbon and total $\mathrm{N}$ increased up to $66 \%$ and 39\%, respectively. Increased enzymatic activities and microbial biomass were also observed in soil after the application of sewage sludge compost when compared to un-amended control. A higher richness and evenness among the soil plots amended with sewage sludge compost was observed, with no significant differences among the application dose rates, when compared to the un-amended soil control and soil treated with a mineral fertilizer. A three-year amendment was able to separate soil plots amended with high doses of sewage sludge compost from the low dose amended and control samples. Among the microbial groups responsible for such marked separation, bacteria belonging to Actinobacteria, Acidobacteria, Cyanobacteria and Bacteroidetes contribute the most, with a shift from oligotrophic to copiotrophic taxa. Significant changes in bacterial composition and taxonomic structure should be considered in order to properly balance agronomic and economic advantages with environmental concerns. After all, our results have evidenced the effects of sewage sludge amendment on different soil properties, microbial activity, and composition already after a short period of application. The findings are particularly relevant in semiarid soils, where an immediate restoration of soil fertility by short-term compost application is needed. 
Keywords: bacterial diversity; microbial biomass; $16 \mathrm{~S}$ rRNA; soil enzymes activities

\section{Introduction}

Sewage sludge are residues from different categories of solid waste (mainly industrial, commercial and residential sectors) as well as from urban wastewaters. The global production of sewage sludge and, in general, of solid waste, reveals a trend that is growing increasingly fast [1]. Since sewage sludge usually contain organic compounds, macronutrients, and a wide range of micronutrients, they provide numerous opportunities for beneficial use in agriculture. Sewage sludge has been reported to improve soil fertility by replacing mineral fertilizers [2]. Land application of sewage sludge has led to increased soil $\mathrm{pH}$ or decreased $\mathrm{pH}$ values [3,4], increased electrical conductivity [5], macronutrients $(\mathrm{N}, \mathrm{P}$, and K) [6] and soil organic carbon stock [7]. Aggregate stability, bulk density, porosity, and water retention may be also improved and, in turn, positively affect plant nutrient balance and, consequently, crop production and quality $[8,9]$.

The adoption of urban sewage sludge as organic amendment is, therefore, tied to its quality, closely related to its composition, wastewater treatment, and subsequent stabilization process [10]. The hidden presence of toxic compounds such as heavy metals [11,12], pharmaceutics [13], hormones [14], aromatic hydrocarbons [15], and pathogen microorganisms [16] should be cautiously taken into account. To overcome these risks, sewage sludge is usually composted $[17,18]$. Studies on sewage sludge compost showed a significant decrease of the heavy metal content [19], leaching of nitrate [20], deletion of pathogens [21] as well as useful humification degree of the organic matter resulting in a more stable and mature organic carbon form [22].

Sewage sludge land application in agriculture as integrated management strategies to improve soil quality and crop production has been studied since the 2000s [23]. Besides some relevant changes on physicochemical soil parameters, effects of sewage sludge amendment on biochemical properties (e.g., microbial biomass C, enzyme activities, basal respiration) were also reported [1,24,25], as well as on the microbial community structure and diversity $[26,27]$.

To date, the effects of sewage sludge were largely explored in different soil type targeting some specific soil components. The sewage sludge application on a semiarid region like Mediterranean soils, as well as the adoption of a range of dose rates, and the effects on different soil properties, were instead scarcely investigated.

Considering the potential ameliorations deriving from the application of sewage sludge compost on soil fertility and crop production in semiarid soils, as well as the opportunities for its virtuous recycling in a sustainable way, the study aimed to evaluate the three-year cumulative effects of different doses of sewage sludge compost on a soil cultivated under crop rotation (potato, wheat, barley) in pot experiments. The objectives of the present research were to evaluate the effects of four different dose rates of sewage sludge compost from urban wastewater on the physicochemical, hydrological, biochemical parameters, and microbial composition under controlled conditions, in a three-year crop rotation system sewage sludge compost.

\section{Materials and Methods}

\subsection{Experimental Design and Soil Sampling}

The research was performed in the experimental fields of the University of Bari $\left(41^{\circ} 06^{\prime} 35^{\prime \prime} \mathrm{N}\right.$ and $\left.16^{\circ} 52^{\prime} 57^{\prime \prime} \mathrm{E}\right)$. A completely randomized block experimental design comprising 6 replicates pots $\left(\varnothing=0.80 \mathrm{~m}, \mathrm{~h}=0.60 \mathrm{~m}\right.$, volume $\left.=240 \mathrm{dm}^{3}\right)$ filled with sandy-loam soil were arranged under open field conditions (Figure S1).

Seven experimental plots ( 5 doses and 2 controls) were compared. The soil management encompassed one control-plot without amendment ( $\mathrm{C} 0)$; four different compost-amended plots with 
increasing doses (3-6-9-12 Mg/ha) of a sewage sludge compost of urban origin corresponding to the treatments C3, C6, C9, C12, respectively; one amended-plot with $6 \mathrm{Mg} /$ ha sewage sludge combined with $60 \mathrm{~kg} / \mathrm{ha}$ of ammonium nitrate $(\mathrm{C} 6 \mathrm{~N})$; and one amended-control-plot with a mineral fertilizer (Min). For the Min plots in particular, the $\mathrm{N}_{,} \mathrm{P}_{2} \mathrm{O}_{5}$ and $\mathrm{K}_{2} \mathrm{O}$ dose rate varied for the different crops as follows: 150, 100, and $250 \mathrm{~kg} / \mathrm{ha}$ for potatoes; 120,100 , and $100 \mathrm{~kg} / \mathrm{ha}$ for wheat; 120,70 , and $70 \mathrm{~kg} / \mathrm{ha}$ for barley.

The sewage sludge compost from municipal wastewater was produced by ASECO, Ginosa Marina (TA) Italy. The composting technique, lasting around 110 days, concerned of: (i) a stabilized sewage sludge originating from an urban wastewater treatment plant which was mixed with green wastes from agro-food industries (wine pomace, tomatoes and oranges peels) and mowing/pruning material (wheat straw and pruning of olive, grapevine and citrus trees) previously chopped; (ii) aerobic bio-stabilization by active composting time by forced aeration and recirculation reaching moisture $>50 \%, 65-70{ }^{\circ} \mathrm{C}$ temperature and $\mathrm{O}_{2}>15 \%$; (iii) maturation (curing) at temperature $<45^{\circ} \mathrm{C}$ performed with frequent mixing up; (iv) percolate separation; and (v) compost refining by sieving through a $2 \mathrm{~mm}$ sieve at field moisture condition. Sewage sludge compost was produced according to the heavy metals and bacteriological legal limits imposed by the Italian Legislative Decree No. 217 of 29 April 2006 [28].

Sewage sludge compost was buried and accurately incorporated into the topsoil at the maximum depth of $60 \mathrm{~cm}$ by manual mixing. We have used the following doses: $0.18,0.35,0.53$ and $0.70 \mathrm{~kg} / \mathrm{pot}$ for the treatments C3, C6, C9 and C12, respectively. These doses were selected according to the requests of organic amendment with compost on potato-wheat-barley succession, in South Italy. Crop-seedbed preparation occurred after two months from the compost application. Sewage sludge compost was added for three consecutive years before each crop seeding. The sowing of potato (cv. Sieglinde) was carried out on January of the first year, while the seeding of the wheat (cv. Simeto) and barley (cv. Nure) were carried out on December and November of the following years, respectively.

Immediately after seeding of each crop, irrigation was carried out on the soil surface $(0-0.20 \mathrm{~m})$ until field capacity. During the irrigation season, pots were irrigated when the water loss exceeded $30 \%$ of the maximum available water (MAW) for potato and of $50 \%$ the MAW for wheat and barley. Seeds were sowed at the following density: 10,450 and 350 seeds $/ \mathrm{m}^{2}$ for potato, wheat and barley, respectively; a manual weed control was carried out when needed.

Soil samples were collected from each pot at 0-0.60 m depth after the three-year period of continuous amendment and immediately after barley harvest (June). Soil samples were air dried and sieved at $2 \mathrm{~mm}$ for determining the soil physicochemical and hydrologic analysis or stored at $-20^{\circ} \mathrm{C}$ for assessing the soil enzymatic activities, microbial biomass, and bacterial community composition.

Soil properties and main chemical-physical characteristics of the soil and sewage sludge compost are reported in Table 1.

\subsection{Soil Physicochemical and Hydrological Properties}

The following physicochemical properties of the potting soils were evaluated: electrical conductivity (ECe) and $\mathrm{pH}$ of the saturation extract; total nitrogen $(\mathrm{N})$, determined using the Kjeldahl method [29]; available phosphorous (P), determined using the method of Watanabe and Olsen (1965) and extracting $\mathrm{P}$ with $0.5 \mathrm{M}$ solution of $\mathrm{NaCO}_{3} \mathrm{H}$ [29]; exchangeable potassium (K), extracted using a solution of barium chloride and triethanolamine (TEA) $\left(100 \mathrm{~g}\right.$ of $\mathrm{BaCl}_{2} \cdot 2 \mathrm{H}_{2} \mathrm{O}$ with $22.5 \mathrm{~mL}$ of TEA adjusted to $\mathrm{pH} 8.2$ using $1 \mathrm{M} \mathrm{HCl}$ ) and measured by atomic absorption spectrophotometer [29]; and the total organic matter content, measured using the modified Walkley-Black method [30].

The soil structure stability values were measured on 1-2 mm aggregates by water sieving with or without pre-treatment in alcohol [31]. For soil water retention curves, six undisturbed soil cores were collected from each pot by gently hand-hammering stainless-steel cylinders $(5 \mathrm{~cm}$ height and $8 \mathrm{~cm}$ diameter) into the surface horizon of the soil after the first few centimeters $(<3 \mathrm{~cm})$ had been removed. From saturation $(0 \mathrm{MPa})$ to field capacity $(-0.33 \mathrm{MPa})$ and the wilting point $(-15 \mathrm{MPa})$, polyamide pressure membranes with pores $(\varnothing=0.45 \mu \mathrm{m})$ for Richards' plates were used. 
Table 1. Soil properties and main chemical-physical characteristics of the soil and sewage sludge compost.

\begin{tabular}{|c|c|c|}
\hline Soil & Parameter & Value $^{a}$ \\
\hline \multirow[t]{3}{*}{ Particle size distribution } & Total sand $(2>\emptyset>0.02 \mathrm{~mm})(\mathrm{g} / \mathrm{kg})$ & $605 \pm 5.11$ \\
\hline & Silt $(0.02>\emptyset>0.002 \mathrm{~mm})(\mathrm{g} / \mathrm{kg})$ & $200 \pm 3.14$ \\
\hline & Clay $(\emptyset<0.002 \mathrm{~mm})(\mathrm{g} / \mathrm{kg})$ & $195 \pm 2.40$ \\
\hline \multirow[t]{10}{*}{ Chemical properties } & Total nitrogen (Kjeldahl method) (g/kg) & $0.9 \pm 0.01$ \\
\hline & Available phosphorus (Olsen method) (mg/kg) & $22.5 \pm 0.75$ \\
\hline & Exchangeable potassium $\left(\mathrm{BaCl}_{2}\right.$ method $)(\mathrm{mg} / \mathrm{kg})$ & $252 \pm 3.58$ \\
\hline & Organic matter (Walkley Black method) (g/100 g) & $1.6 \pm 0.04$ \\
\hline & Total limestone $(\mathrm{g} / 100 \mathrm{~g})$ & $2.6 \pm 0.03$ \\
\hline & Active limestone (g/100 g) & $1.4 \pm 0.01$ \\
\hline & $\mathrm{pH}$ & $7.3 \pm 0.24$ \\
\hline & $\mathrm{ECe}(\mathrm{dS} / \mathrm{m})$ & $0.4 \pm 0.09$ \\
\hline & ESP & $0.8 \pm 0.02$ \\
\hline & CEC ( $\mathrm{BaCl}_{2}$ method) (meq/100 g of soil d.m.) & $20.2 \pm 0.36$ \\
\hline \multirow[t]{3}{*}{ Hydrologic properties } & Field capacity (g/kg of soil d.m.) & $236 \pm 4.59$ \\
\hline & Wilting point (-1.5 MPa) (g/kg of soil d.m.) & $125 \pm 2.16$ \\
\hline & Bulk density $\left(\mathrm{t} / \mathrm{m}^{3}\right)$ & $1.4 \pm 0.35$ \\
\hline \multirow[t]{20}{*}{ Sewage Sludge Compost } & Parameter & Value $^{b}$ \\
\hline & $\mathrm{pH}$ & 7.7 \\
\hline & Humidity (g/100 g) & 23 \\
\hline & Organic carbon (g/100 g d.m.) & 22 \\
\hline & Total nitrogen (g/100 g d.m.) & 1.1 \\
\hline & Organic nitrogen (\% of total $\mathrm{N})$ & $>80$ \\
\hline & $\mathrm{C} / \mathrm{N}$ & 20 \\
\hline & Total phosphorus (g/100 g d.m.) & 2.3 \\
\hline & Total potassium (g/100 g d.m.) & 1.2 \\
\hline & Humic and fulvic acids (g/100 g d.m.) & $>7$ \\
\hline & $\mathrm{Pb}(\mathrm{mg} / \mathrm{kg})$ & $<140$ \\
\hline & $\mathrm{Cd}(\mathrm{mg} / \mathrm{kg})$ & $<1.5$ \\
\hline & $\mathrm{Ni}(\mathrm{mg} / \mathrm{kg})$ & $<100$ \\
\hline & $\mathrm{Zn}(\mathrm{mg} / \mathrm{kg})$ & $<500$ \\
\hline & $\mathrm{Cu}(\mathrm{mg} / \mathrm{kg})$ & $<230$ \\
\hline & $\mathrm{Hg}(\mathrm{mg} / \mathrm{kg})$ & $<1.5$ \\
\hline & $\mathrm{Cr}(\mathrm{mg} / \mathrm{kg})$ & $<0.5$ \\
\hline & Salinity (meq/100 g d.m.) & 21.00 \\
\hline & Particle size (mm) & 15 \\
\hline & Bulk density $\left(\mathrm{kg} / \mathrm{m}^{3}\right)$ & 600 \\
\hline
\end{tabular}

a Values represent the mean \pm SD; ECe = saturation extract electrical conductivity; ESP = exchangeable sodium percentage; $\mathrm{CEC}=$ cation exchange capacity; ${ }^{\mathrm{b}}$ Data given by the ASECO company; d.m.: dry matter.

\subsection{Soil Biological Properties}

Beta-glucosidase and alkaline phosphatase activities of the potting soils were measured and expressed as $\mu \mathrm{g} p$-nitrophenol/g/h [32]; FDA (3'-6'-diacetyl fluorescein) hydrolysis was determined and expressed as $\mu \mathrm{g}$ fluorescein/g/3 h [33].

Soil microbial biomass was determined by the chloroform fumigation-extraction method [34]. The values were expressed on the basis of dry weight soil.

\subsection{Soil Bacterial Microbiome Characterization}

For the analysis of soil bacterial composition, DNA was directly extracted from $0.5 \mathrm{~g}$ of soil using the commercial kit Fast DNA Spin Kit for Soil (MP Biomedicals, Irvine, CA, USA) combined with the Fast Prep System (BIO 101) homogenizer according to the manufacturer's instructions. DNA quantity was verified using a NanoDrop ND-1000 ultraviolet-visible (UV-Vis) spectrophotometer (Thermo-Fisher Scientific Inc., MI, Italy), and by agarose gel electrophoresis. Extracted DNA were stored at $-20^{\circ} \mathrm{C}$ until polymerase chain reaction (PCR) amplification and metagenomic sequencing. 
The DNA extracted from each soil pot (3 replicates $\times 7$ treatments) was used to amplify the V3-V4 region of the 16S-rRNA gene using the universal primers 341F (5'-CCTACGGGNGGCWGCAG-3') and 785R (5'-GACTAACHVGGGTATCTAATCC-3') [35]. The reaction was carried out in $50 \mu 1$ volumes containing $4 \mathrm{mg} / \mathrm{mL}$ BSA (Bovine Serum Albumin), $250 \mu \mathrm{M}$ dTNPs, $0.25 \mu \mathrm{M}$ of each primer, $3 \mathrm{U}$ of Taq DNA polymerase (EuroTaq; EuroClone, Milan, Italy), $2.5 \mathrm{mM} \mathrm{MgCl}$, and 20-40 ng of template DNA. The following PCR conditions were used: initial denaturation $95^{\circ} \mathrm{C}$ for $7 \mathrm{~min}$, followed by 25 cycles consisting of denaturation $\left(95^{\circ} \mathrm{C}\right.$ for $\left.40 \mathrm{~s}\right)$, annealing $\left(55^{\circ} \mathrm{C}\right.$ for $\left.2 \mathrm{~min}\right)$, extension $\left(72{ }^{\circ} \mathrm{C}\right.$ for $1 \mathrm{~min}$ ) and a final extension step at $72{ }^{\circ} \mathrm{C}$ for $7 \mathrm{~min}$. Successful PCR amplification was verified by $1.5 \%$ agarose gel electrophoresis. Amplicons were quantified by using NanoDrop ND-1000 UV-Vis spectrophotometer (Thermo-Fisher Scientific Inc., MilanI, Italy). Equimolar concentrations of the amplicons were subject to paired-end sequencing $(2 \times 300 \mathrm{bp})$ on the Illumina MiSeq platform (IGA Technology Services s.r.l., Udine, Italy). Raw sequence data are available at the National Center for Biotechnology Information (NCBI) under the SRA accession: PRJNA637321.

\subsection{Statistical Analysis and Bioinformatics}

Statistical differences of all physicochemical, hydrological, and biological parameters were compared by one-way analysis of variance (ANOVA-PROC GLM) using the SAS software (SAS Institute, Charlotte, NC, USA). Mean values from five means per sample were separated by the Student-Newman-Keul (SNK) test at $p \leq 0.01$ when ANOVA resulted significant. For the diversity indices, one-way ANOVA was carried out from three means per sample, and value separated by the SNK test at $p<0.05$ by the SPSS package (SPSS Inc., v.24, Chicago, IL, USA).

Raw reads produced by Illumina sequencing were processed by Mothur software v.1.39.5 [36]. Following the standard operating procedure (SOP, http://www.mothur.org/wiki/MiSeq_SOP) sequences were first denoised, trimmed, aligned, and then classified using SILVA bacterial taxonomy database [37]. Heatmap based on bacterial relative abundance at phylum level was built to highlight differences between soil samples by using PermutMatrix software with Euclidean distance [38]. Operational taxonomic units (OTUs) were obtained by clustering sequences at similarity cut-off of $97 \%$ and used to infer alpha (composition) and beta (structure) bacterial diversity.

The $\alpha$-diversity of the bacterial community was evaluated by rarefaction curves measuring the Shannon, Simpson, Chao1, and Abundance-based Coverage Estimator (ACE) diversity indices. Similarity percentage (SIMPER) analysis was undertaken using PAST software [39] to identify OTUs responsible for the differences between sample. The $\beta$-diversity of the bacterial community was evaluated by non-metric multidimensional scaling (NMDS) that was generated using distance matrix to compare and plot the membership and structure of the various samples. 95\% confidence ellipses were shown around samples grouped based on different soil treatments. Canonical correspondence analysis (CCA) was used to relate abundances of species to environmental variables. A graphic interpretation by tri-plot on the two dimensions of the main principal axes was obtained by using PAST software. The CCA model for the tri-plot was significant $(\mathrm{F}=1.34, p=0.004)$.

\section{Results}

\subsection{Physicochemical and Hydrological Parameters}

Figure 1 shows that the electrical conductivity increased from $0.41 \mathrm{dS} / \mathrm{m}(\mathrm{C} 0)$ to $0.53 \mathrm{dS} / \mathrm{m}(\mathrm{C} 12)$ as a consequence of the increasing dose of sewage sludge compost. Nonetheless, no significant differences were observed between the highest dose of sewage sludge compost and the plots amended with mineral fertilizer, both alone (Min) or with $6 \mathrm{Mg} /$ ha sewage sludge compost and $60 \mathrm{~kg} / \mathrm{ha} \mathrm{N}$ (C6N). As expected, the higher was the dose of amendment the higher was the content of organic matter and total N (Figure 1). In detail, organic carbon and total N increased up to $66 \%$ and $39 \%$, respectively, in $\mathrm{C} 12$ pots. Interestingly, a relatively low amount of compost $(6 \mathrm{Mg} / \mathrm{ha})$, with or without the addition of inorganic $\mathrm{N}$ ( $\mathrm{C} 6 \mathrm{~N}$ and $\mathrm{C} 6$ samples, respectively), was able to stimulate a significant increase in both C 
and $\mathrm{N}$ values. It is worth noting that mineral fertilization alone (Min), although positively affecting the amount of total $\mathrm{N}$, did not allow the best results when compared to the organic composted amendment.
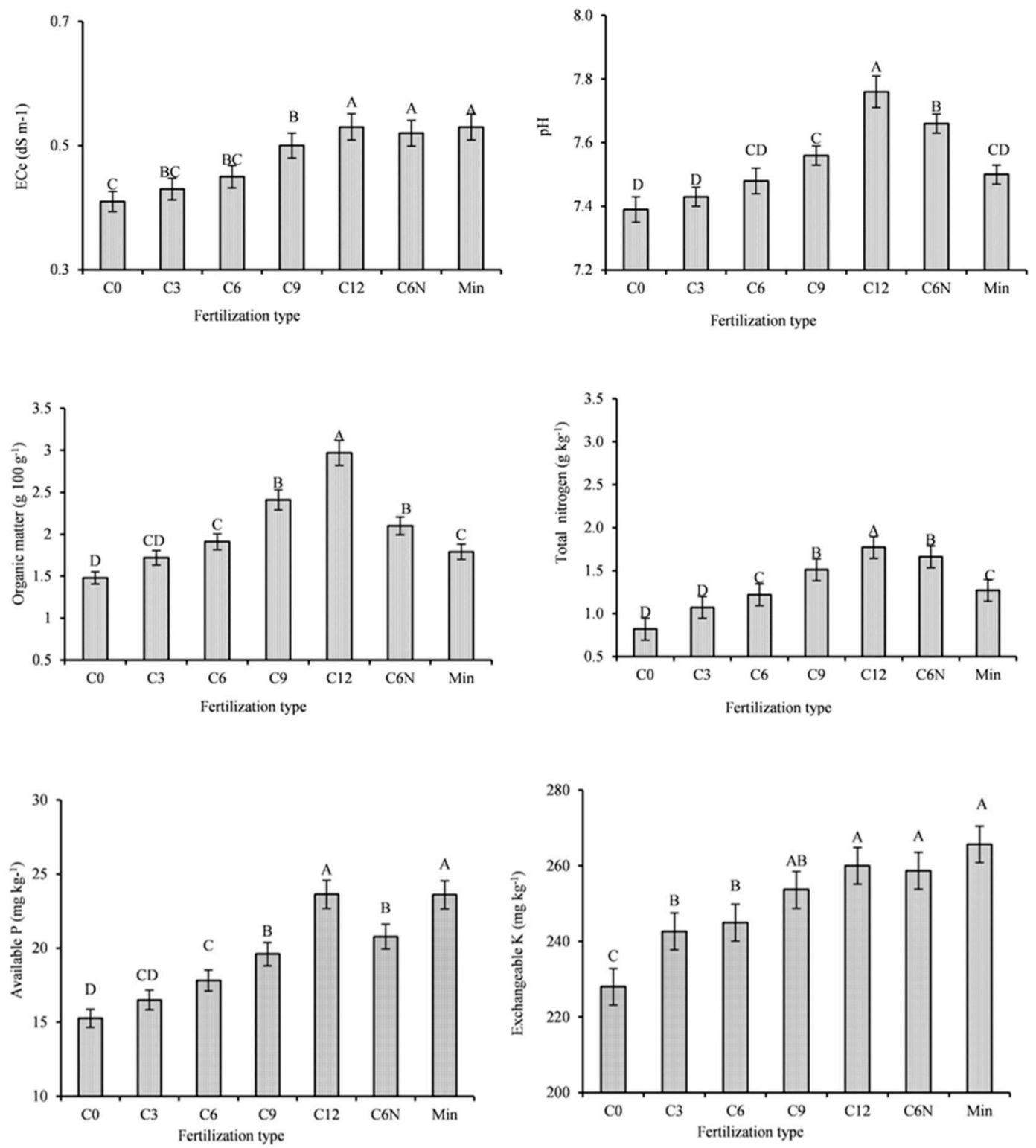

Figure 1. Physicochemical properties of the potting soils amended with increasing doses of sewage sludge compost and supplied by mineral fertilization. C0, unfertilized soil; C3, C6, C9 and C12 = 3, 6, 9 and $12 \mathrm{Mg} /$ ha sewage sludge compost, respectively; $\mathrm{C} 6 \mathrm{~N}$, combined application of $6 \mathrm{Mg} / \mathrm{ha}$ of sewage sludge and $60 \mathrm{~kg} / \mathrm{ha} \mathrm{N}$; Min, mineral fertilization. The values with the same letter are not significantly different, according to the Student-Newman-Keul (SNK) test at $p \leq 0.01$. Vertical bars represent the standard errors of means.

Figure 1 indicates that the available $P$ and exchangeable $K$ contents were increased after amendment with increasing doses of sewage sludge compost. As for the organic $\mathrm{C}$ and total $\mathrm{N}$ content, the higher the dose of amendment, the higher was the increase in $\mathrm{P}$ and $\mathrm{K}$ content. In particular, the available $\mathrm{P}$ content was almost doubled by $12 \mathrm{Mg} / \mathrm{ha}$, while exchangeable $\mathrm{K}$ increase of about $15 \%$ when compared to control C0. Obviously, the direct addition of mineral forms of these two nutrients (Min) brings to a rapid and very high increase, too. Noteworthy, as for $\mathrm{C}$ and $\mathrm{N}$ content, low dose amendments (C3-C6) even after a short term (3 years), significantly improved soil $\mathrm{P}$ and $\mathrm{K}$ available for plant mineral nutrition. 
Figure 2 shows that the stability structure index significantly increase as the dose of sewage sludge compost increased. When compared to not amended soil pots, values increased up to $43 \%$ (in water) and $55 \%$ (after alcohol treatment).
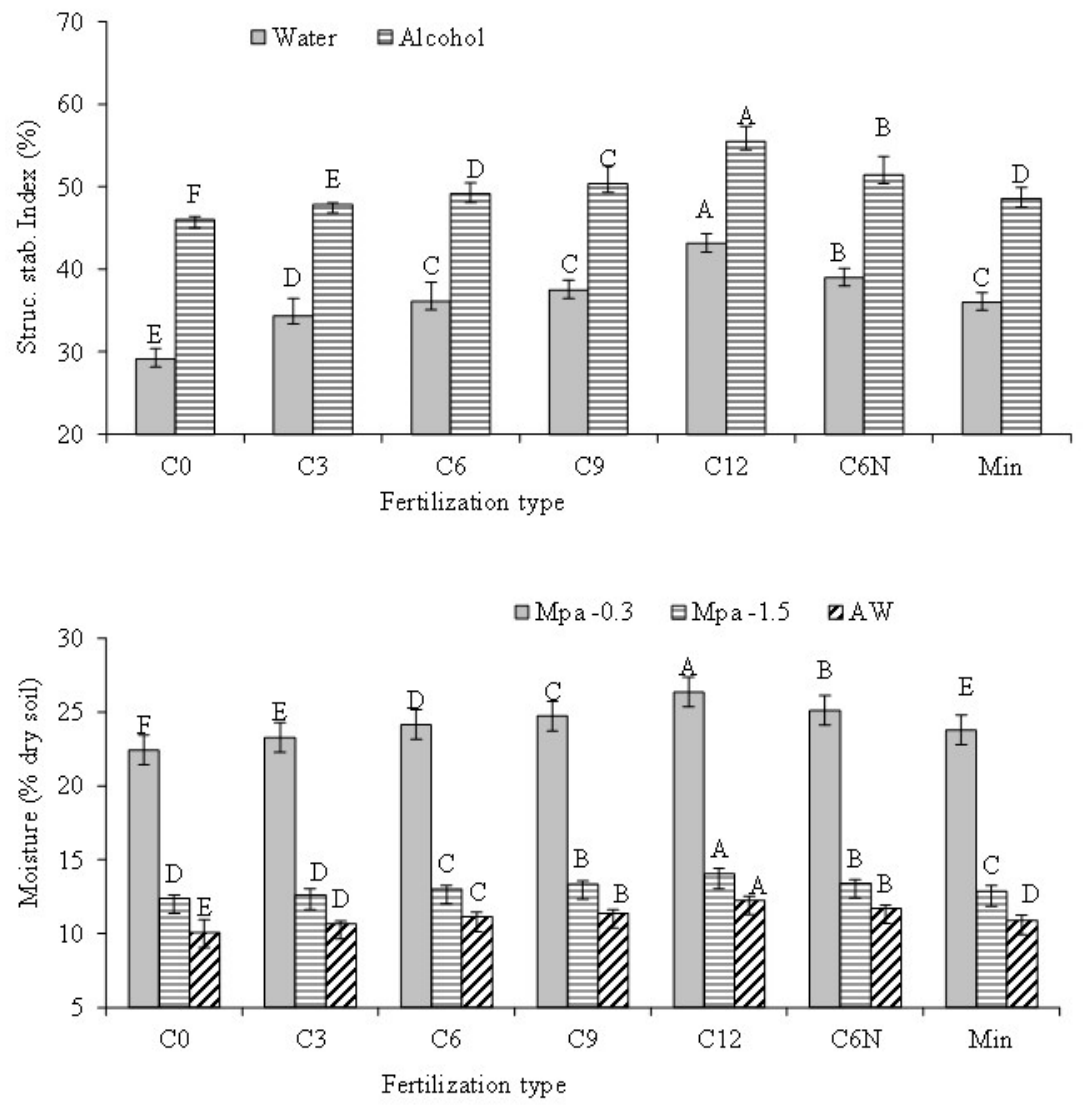

Figure 2. Structure stability and hydrologic properties of the potting soils amended for three-years with increasing doses of sewage sludge compost and supplied by mineral fertilization. Mpa: Mega Pascal; AW: available water. C0, unfertilized soil; C3, C6, C9 and $\mathrm{C} 12=3,6,9$ and $12 \mathrm{Mg} / \mathrm{ha}$ sewage sludge compost, respectively; $6 \mathrm{~N}$, combined application of $6 \mathrm{Mg} / \mathrm{ha}$ of sewage sludge and $60 \mathrm{~kg} / \mathrm{ha} \mathrm{N}$; Min, mineral fertilization. The values with the same letter are not significantly different, according to the SNK test at $p \leq 0.01$. Vertical bars represent the standard errors of means.

The percent of moisture of the dry soil at the field capacity (-0.3 Mpa) and at the wilting point $(-1.5 \mathrm{Mpa})$ increased up to $26 \%$ and $14 \%$ of the C0 not amended control, respectively, when the maximum amount of compost (C12) was added to soil pots; similarly, available water content increased up to $12 \%$ for the same treatment (Figure 2). Anyway, it should be noted that the increase of the hydrological parameters depends on the amounts of compost added to soil. Although statistically significant, it was not so high as for nutrient content (organic C, total N, available $\mathrm{P}$ and exchangeable $\mathrm{K}$ ).

\subsection{Biological Parameters}

Figure 3 shows that the level of measured enzyme activities in soil generally increases by the application of sewage sludge compost or mineral fertilization when compared to control (C0). 

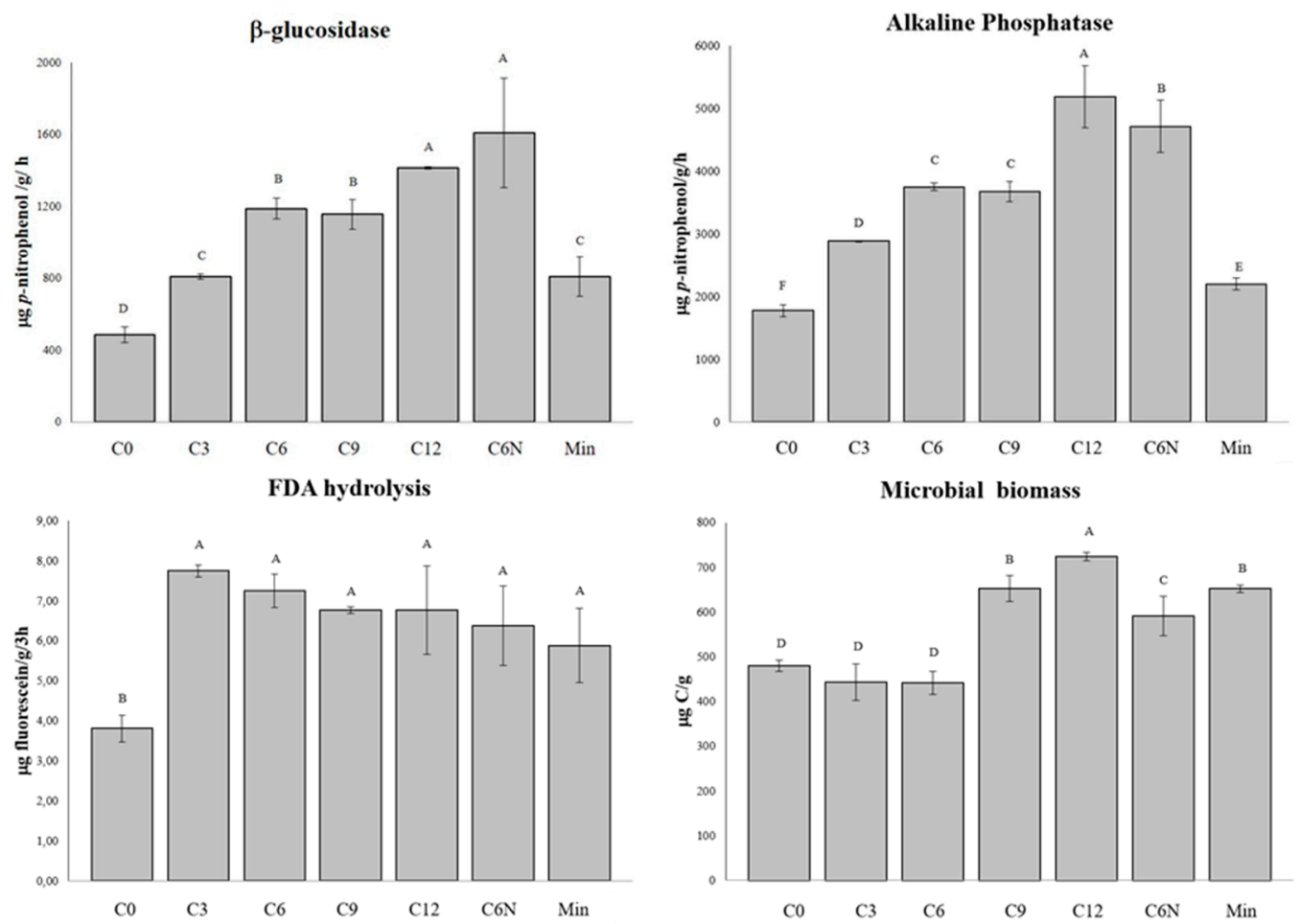

Figure 3. Enzymatic activities and microbial biomass of the potting soils amended for three-years with increasing doses of sewage sludge compost and supplied by mineral fertilization. $\mathrm{C} 0$, unfertilized soil; C3, C6, C9 and C12 = 3, 6, 9 and $12 \mathrm{Mg} /$ ha sewage sludge compost, respectively; C6N, combined application of $6 \mathrm{Mg} / \mathrm{ha}$ of sewage sludge and $60 \mathrm{~kg} / \mathrm{ha} \mathrm{N}$; Min, mineral fertilization. The values with the same letter are not significantly different, according to the SNK test at $p \leq 0.01$. Vertical bars represent the standard errors of means.

The $\beta$-glucosidase activity significantly increased with increasing application rates of sewage sludge compost, with the higher level in $\mathrm{C} 12$ and $\mathrm{C} 6 \mathrm{~N}$, while the activity in soil treated with mineral fertilization was slightly higher than the un-amended control (C0).

The alkaline phosphatase activity significantly increased linearly with increasing application rates of sewage sludge; as for $\beta$-glucosidase, the alkaline phosphatase activity reached the maximum level in pots amended with the highest amounts of sewage sludge compost (C12) and lower sludge implemented with mineral $(\mathrm{C} 6 \mathrm{~N})$ and was slightly higher than the control.

FDA hydrolysis significantly increased, no matter the different amounts of amendment as well as the inorganic fertilization compared to the control.

Soil microbial biomass significantly increased with the application of higher rates of sewage sludge (C9 and C12), lower amounts of sludge implemented with $\mathrm{N}(\mathrm{C} 6 \mathrm{~N})$ and mineral fertilization (Min), while no differences were found between the control soil and the soil treated with lower levels of sewage sludge.

\subsection{Bacterial Community Composition and Diversity}

Illumina sequencing produced a total of 953,639 reads, reduced to 484,101 reads after a quality control, for the entire set of pots. Clustering of sequences to $97 \%$ similarity produced a total of 20,026 OTUs. Rarefaction curves drawn by plotting the number of sequences and the OTUs associated to each soil sample showed that, at the current sequencing depth, unexplored OTUs still remain for all soil samples (Figure 4). 


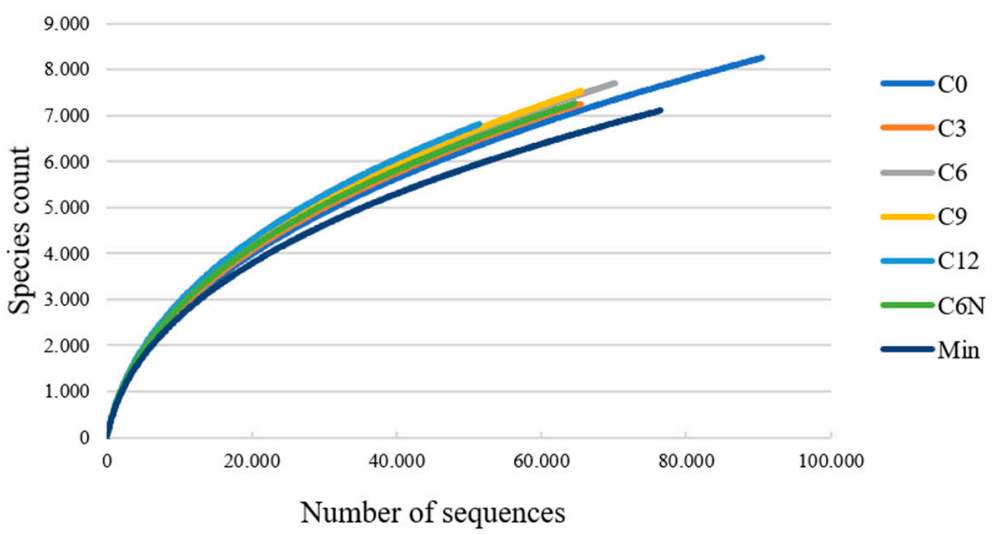

Figure 4. Rarefaction curves of the complete dataset of sequences. C0, unfertilized soil; C3, C6, C9 and $\mathrm{C} 12=3,6,9$ and $12 \mathrm{Mg} /$ ha sewage sludge compost, respectively; $6 \mathrm{~N}$, combined application of 6 $\mathrm{Mg} / \mathrm{ha}$ of sewage sludge and $60 \mathrm{~kg} / \mathrm{ha} \mathrm{N}$; Min, mineral fertilization.

Considering the different size of sequences among samples (Table 2), a reduced dataset was built randomly selecting, for each sample, 51,390 sequences (corresponding to the lowest number of sequences, C12). Table 2 also shows the $\alpha$-diversity indices such as richness and evenness (Shannon, Simpson, Chao1, and ACE) calculated on the reduced dataset for each soil sample. Shannon and Simpson indices indicated that the richness of bacterial communities of sewage sludge-amended soil are similar and higher than richness present either in control soil pots (CO) or in soil amended with chemical fertilization (Min). Chao1 and ACE values showed lower significant differences, with the main exception of Min sample that had the lowest richness and diversity.

Table 2. Alpha-diversity indices of soil microbial communities under different treatments *.

\begin{tabular}{cccccc}
\hline Samples & Good Quality Sequences & Shannon & Simpson & Chao1 & ACE $^{* *}$ \\
\hline C0 & 90,427 & $7.28^{\mathrm{b}}$ & $334.52^{\mathrm{b}, \mathrm{c}}$ & $11,209^{\mathrm{b}}$ & $14,353^{\mathrm{a}}$ \\
C3 & 65,487 & $7.34^{\mathrm{a}, \mathrm{b}}$ & $362.51^{\mathrm{a}}$ & $11,260^{\mathrm{b}}$ & $14,529^{\mathrm{a}}$ \\
C6 & 70,214 & $7.40^{\mathrm{a}}$ & $419.76^{\mathrm{a}}$ & $11,703^{\mathrm{a}}$ & $15,023^{\mathrm{a}}$ \\
C9 & 65,505 & $7.43^{\mathrm{a}}$ & $425.40^{\mathrm{a}}$ & $11,718^{\mathrm{a}}$ & $14,904^{\mathrm{a}}$ \\
C12 & 51,390 & $7.46^{\mathrm{a}}$ & $418.12^{\mathrm{a}}$ & $11,503^{\mathrm{a}}$ & $14,286^{\mathrm{a}}$ \\
C6N & 64,625 & $7.36^{\mathrm{a}, \mathrm{b}}$ & $355.51^{\mathrm{b}}$ & $11,285^{\mathrm{b}}$ & $13,908^{\mathrm{b}}$ \\
Min & 76,453 & $7.18^{\mathrm{c}}$ & $283.81^{\mathrm{c}}$ & $10,270^{\mathrm{c}}$ & $12,967^{\mathrm{b}}$ \\
\hline
\end{tabular}

* Diversity indices are calculated on normalized dataset (51,390 sequences). ${ }^{* * A C E: ~ A b u n d a n c e-b a s e d ~ C o v e r a g e ~}$ Estimator. They are means of three replicates for each sample; data with different letters in each column are significantly different, according to SNK test at $p<0.05$. C0, unfertilized soil; C3, C6, C9 and C12 = 3, 6, 9 and $12 \mathrm{Mg} /$ ha sewage sludge compost, respectively; $6 \mathrm{~N}$, combined application of $6 \mathrm{Mg} / \mathrm{ha}$ of sewage sludge and 60 $\mathrm{kg} / \mathrm{ha} \mathrm{N}$; Min, mineral fertilization.

Taxonomic classification of reads allowed 19 bacterial phyla to be identified. A quite similar taxonomic profile emerged among soil samples (Figure 5a). Proteobacteria and Actinobacteria were the dominant phyla ( $\sim 9 \%$ of total sequences). Other dominant phyla were Planctomycetes and Acidobacteria, represented respectively by $\sim 11 \%$ and $8 \%$ of sequences. A lower percentage of sequences were instead associated to Bacteroidetes (4.9\%), Firmicutes (4.2\%), Chloroflexy (3.5\%), Gemmatimonadetes (2.7\%), Verrucomicrobia $(2.1 \%)$, and Cyanobacteria $(1.1 \%)$. Other phyla were represented by a relative abundance $<1 \%$. Almost $10 \%$ of sequences were associated to Bacteria_unclassified. 


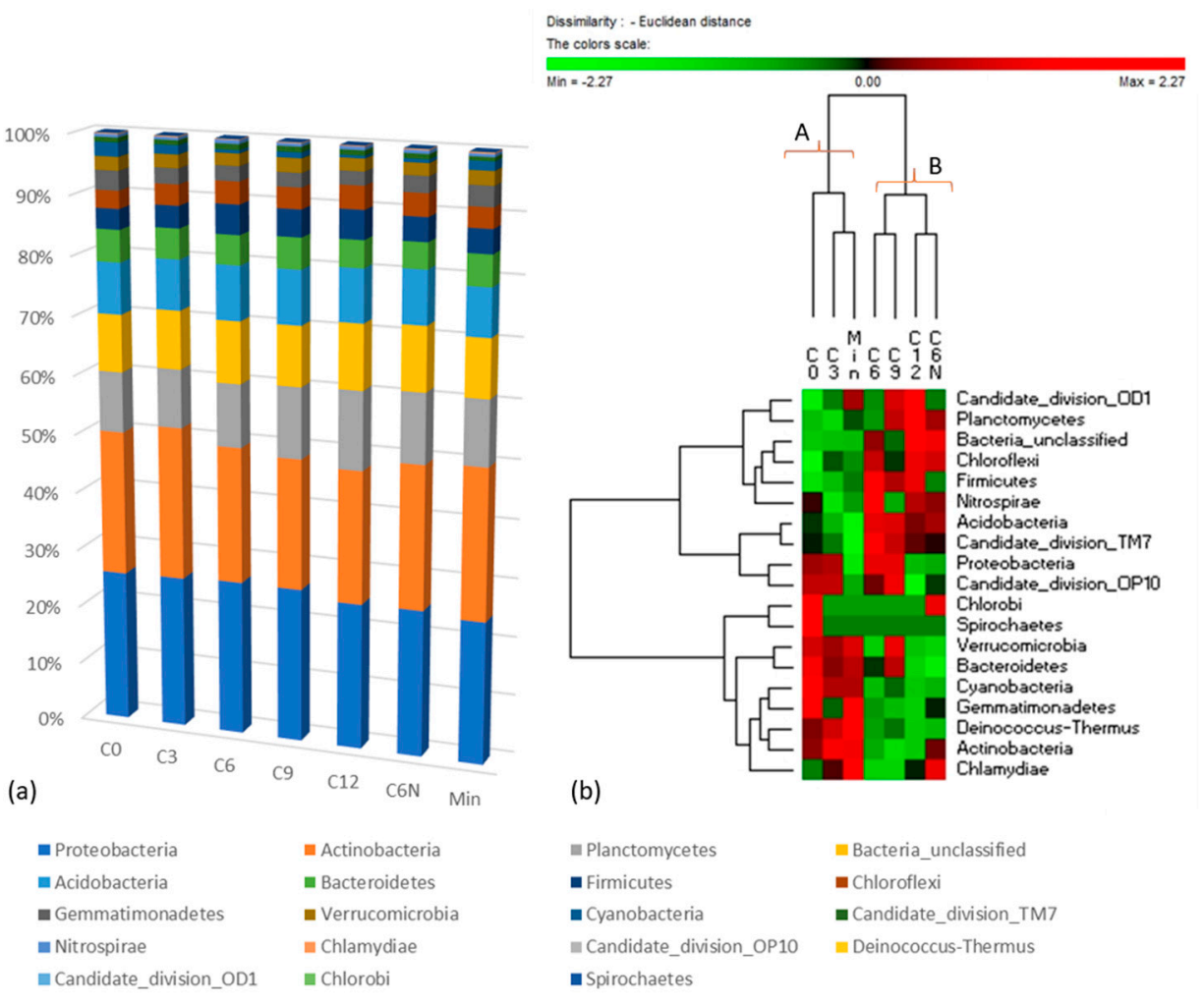

Figure 5. Bacterial composition of the soil samples. (a) Relative abundance of phyla associated to soil samples; (b) Heatmap showing bacterial diversity (at phylum level) across the different soil managements. $\mathrm{C} 0$, unfertilized soil; $\mathrm{C} 3, \mathrm{C} 6, \mathrm{C} 9$ and $\mathrm{C} 12=3,6,9$ and $12 \mathrm{Mg} /$ ha sewage sludge compost, respectively; C6N, combined application of $6 \mathrm{Mg} / \mathrm{ha}$ of sewage sludge and $60 \mathrm{~kg} / \mathrm{ha} \mathrm{N}$; Min, mineral fertilization.

Despite this apparent homogeneity, permutation analysis on relative abundance at the phylum level allowed to cluster soil samples into two groups (group A and group B) (Figure 5b). The unamended soil (C0), the chemical fertilized soil (Min), and the soil with the lower dose of sewage sludge compost (C3) were clustered in the group A in comparison to the soils amended with higher doses of the sewage sludge compost $(\mathrm{C} 6, \mathrm{C} 6 \mathrm{~N}, \mathrm{C} 9, \mathrm{C} 12$,) that clustered in the group $\mathrm{B}$, such highlighting a shift in bacterial composition based on the different rates of sewage sludge compost applied.

The soil samples of group A (C0, C3, and Min) were dominated by Chlorobi, Spirochaetes, Verrucomicrobia, Bacteroidetes, Cyanobacteria, Gemmatimonadetes, Deinococcus, Actinobacteria, and Chlamydiae. The soil samples of group B $(\mathrm{C} 6, \mathrm{C} 9, \mathrm{C} 12, \mathrm{C} 6 \mathrm{~N})$ were instead abundantly colonized by candidate divisions (OD1, TM7 and OP10), Planctomicetes, Bacteria unclassified, Chloroflexy, Firmicutes, Nitrospirae, Acidobacteria, and Proteobacteria.

The SIMPER analysis (Table 3) on the relative abundance of OTUs at class level revealed that OTUs belonging to Actinobacteria and Alpha-Proteobacteria mainly contributed to the differences observed among soil samples with a dissimilatory contribution of about $33 \%$ and $14 \%$, respectively, many times higher than those of other OTUs whose values ranged from about $7 \%$ to less than $1 \%$. Interestingly, the number of sequences belonging to each OTU is always higher for unamended control C0 followed by soil pots chemically fertilized (Min); the higher the amounts of sewage sludge compost (C3 to C12) the lower the number of sequences associated to OTUs. This trend is confirmed also for lower represented OTUs, such as the OTUs of Cyanobacteria, whose values ranged from a maximum of 1210 sequences for $\mathrm{C} 0$ to only 6 sequences for $\mathrm{C} 12$. Making comparison between doses, by performing all pairwise comparisons (C3-C6, C6-C9, etc.) (data not reported), we found that above the C6 dose only Actinobacteria OTUs significantly contribute to discriminating between communities, while variations for other microbial groups were non significantly affected by the amount of compost added. 
Table 3. Similarity percentage (SIMPER) analysis showing the principal operational taxonomic units (OTUs) responsible for the differences between treatments *.

\begin{tabular}{|c|c|c|c|c|c|c|c|c|c|}
\hline OTUs & $\begin{array}{l}\text { Dissimilarity } \\
\text { Contribution }\end{array}$ & Cumulative \% & CO & C3 & C6 & C9 & $C 12$ & $\mathrm{C} 6 \mathrm{~N}$ & Min \\
\hline Actinobacteria & 32.71 & 32.71 & 19,714 & 14,927 & 14,048 & 12,539 & 9959 & 13,853 & 17,836 \\
\hline Alphaproteobacteria & 13.97 & 46.67 & 9857 & 7115 & 7868 & 6919 & 5280 & 7078 & 8380 \\
\hline Acidobacteria & 7.06 & 53.74 & 5779 & 4166 & 4883 & 4498 & 3408 & 4405 & 4647 \\
\hline Betaproteobacteria & 5.75 & 59.49 & 4047 & 3087 & 3312 & 2989 & 2111 & 2805 & 3272 \\
\hline Sphingobacteria & 5.17 & 64.65 & 2982 & 2004 & 2141 & 2020 & 1311 & 1750 & 2415 \\
\hline Gemmatimonadetes & 4.63 & 69.29 & 2160 & 1194 & 1159 & 1060 & 729 & 1166 & 1859 \\
\hline Bacteria_unclass. & 4.24 & 73.53 & 3776 & 2896 & 3425 & 2983 & 2660 & 3392 & 3616 \\
\hline Phycisphaerae & 3.97 & 77.5 & 3430 & 2400 & 2890 & 2750 & 2240 & 2640 & 3000 \\
\hline Cyanobacteria & 3.84 & 81.34 & 1210 & 516 & 53 & 242 & 6 & 89 & 530 \\
\hline Bacilli & 2.89 & 84.23 & 1704 & 1263 & 1773 & 1592 & 1143 & 1182 & 1782 \\
\hline Gammaproteobacteria & 2.88 & 87.1 & 1836 & 953 & 1050 & 1331 & 878 & 1053 & 1153 \\
\hline Deltaproteobacteria & 1.75 & 88.85 & 1365 & 1087 & 1184 & 1039 & 760 & 1042 & 1058 \\
\hline Planctomycetacia & 1.34 & 90.19 & 1425 & 1075 & 1248 & 1394 & 1195 & 1344 & 1421 \\
\hline Planctomycetes & 1.33 & 91.53 & 1040 & 745 & 762 & 709 & 686 & 789 & 1016 \\
\hline Thermomicrobia & 1.23 & 92.76 & 931 & 826 & 819 & 739 & 647 & 773 & 1010 \\
\hline Chloroplast & 0.78 & 93.54 & 383 & 200 & 166 & 196 & 100 & 142 & 144 \\
\hline Spartobacteria & 0.74 & 94.28 & 299 & 216 & 171 & 211 & 123 & 172 & 333 \\
\hline SubsectionIV & 0.68 & 94.96 & 219 & 154 & 63 & 65 & 17 & 45 & 29 \\
\hline ОРВ35 & 0.64 & 95.6 & 371 & 365 & 359 & 340 & 176 & 299 & 356 \\
\hline Chloroflexi & 0.64 & 96.24 & 498 & 430 & 558 & 444 & 395 & 452 & 368 \\
\hline Clostridia & 0.47 & 96.71 & 199 & 104 & 155 & 112 & 59 & 79 & 122 \\
\hline Proteobacteria_unclass. & 0.45 & 97.16 & 503 & 436 & 412 & 504 & 417 & 432 & 379 \\
\hline Nitrospira & 0.41 & 97.56 & 342 & 249 & 332 & 260 & 236 & 287 & 273 \\
\hline Anaerolineae & 0.40 & 97.97 & 180 & 76 & 145 & 116 & 64 & 103 & 95 \\
\hline Opitutae & 0.34 & 98.31 & 209 & 178 & 212 & 182 & 126 & 144 & 153 \\
\hline SubsectionIII & 0.31 & 98.62 & 10 & 0 & 0 & 0 & 0 & 3 & 129 \\
\hline Candidate_division_TM7 & 0.30 & 98.92 & 143 & 81 & 148 & 146 & 87 & 125 & 89 \\
\hline Verrucomicrobia & 0.27 & 99.19 & 134 & 26 & 24 & 41 & 31 & 28 & 36 \\
\hline Caldilineae & 0.27 & 99.46 & 294 & 311 & 303 & 324 & 275 & 352 & 329 \\
\hline Firmicutes & 0.25 & 99.71 & 7 & 12 & 43 & 0 & 66 & 24 & 1 \\
\hline Bacteroidetes & 0.17 & 99.88 & 85 & 55 & 67 & 93 & 46 & 66 & 73 \\
\hline Flavobacteria & 0.12 & 100 & 3 & 4 & 25 & 15 & 34 & 19 & 24 \\
\hline
\end{tabular}

* Values associated to each soil samples are the number of sequences belonging to each OTU. C0, unfertilized soil; $\mathrm{C} 3, \mathrm{C} 6, \mathrm{C} 9$ and $\mathrm{C} 12=3,6,9$ and $12 \mathrm{Mg} /$ ha sewage sludge compost, respectively; $6 \mathrm{~N}$, combined application of $6 \mathrm{Mg} / \mathrm{ha}$ of sewage sludge and $60 \mathrm{~kg} / \mathrm{ha} \mathrm{N}$; Min, mineral fertilization.

Further differences among soil treatments emerged exploring the bacterial membership and structure ( $\beta$-diversity). Non-metric multidimensional scaling (NMDS) based on the normalized dataset evidenced two distinct association: C0-Min-C3 and C6N-C6-C9-C12 (Figure 6).

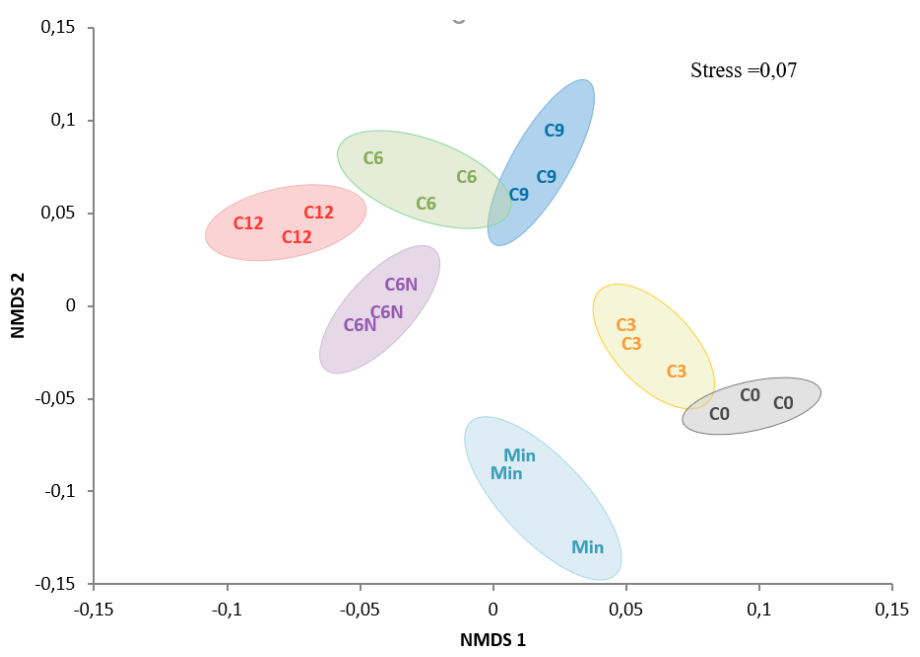

Figure 6. Beta-diversity of the bacterial community evaluated by non-metric multidimensional scaling (NMDS). C0, unfertilized soil; C3, C6, C9 and C12 =3, 6, 9 and $12 \mathrm{Mg} /$ ha sewage sludge compost, respectively; $6 \mathrm{~N}$, combined application of $6 \mathrm{Mg} / \mathrm{ha}$ of sewage sludge and $60 \mathrm{~kg} / \mathrm{ha} \mathrm{N}$; Min, mineral fertilization. 
The impact of different fertilization plans on environmental variables and bacterial communities was examined by CCA. Six axes were identified that accounted for the almost total variance mostly explained by the first two components (86\%) (Figure 7). The score values differentiated the treatments investigated. The first axis, accounting for about $75 \%$ of variance, clearly discriminated C0, C3, Min soil pots from those amended by a greater quantity of sewage sludge $(\mathrm{C} 6, \mathrm{C} 6 \mathrm{~N}, \mathrm{C} 9, \mathrm{C} 12)$. A further division within these two main clusters was accounted for about $12 \%$ by the second axis. It is also relevant to note that higher amounts of compost affected mainly chemical-physical parameters, while the lowest dose (C3) and the unamended control influenced microbial biomass, glucosidase activity and the composition of some bacterial groups.

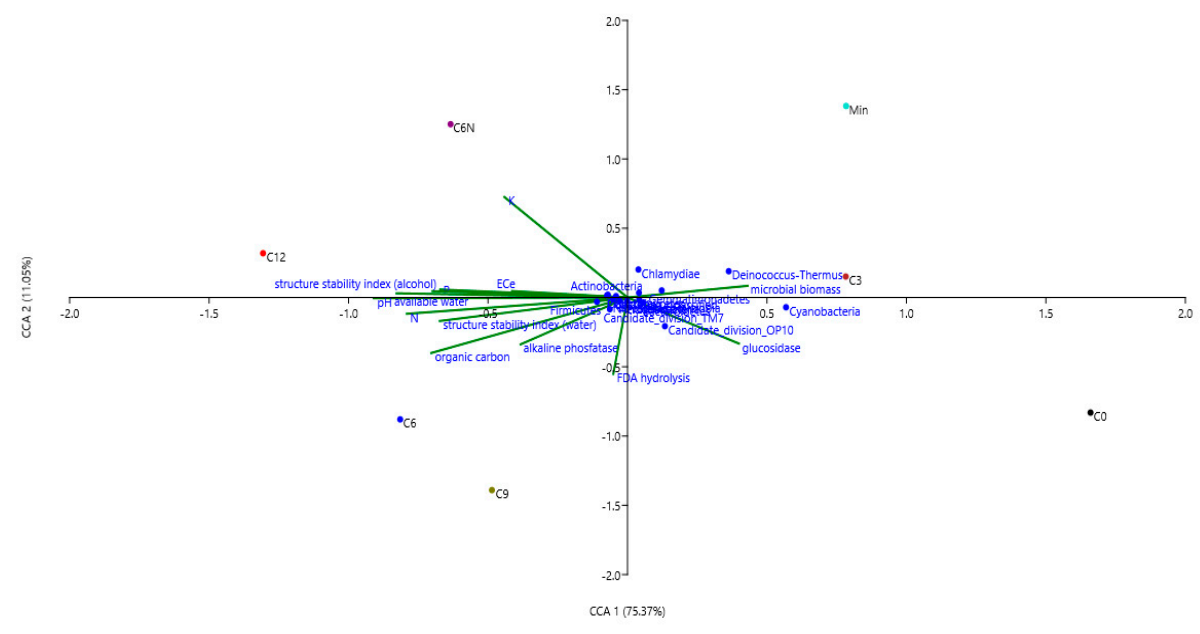

Figure 7. Canonical correspondence analysis (CCA). Relationships between environmental variables and microbial community. C0, unfertilized soil; C3, C6, C9 and C12 =3, 6, 9 and $12 \mathrm{Mg} /$ ha sewage sludge compost, respectively; $\mathrm{C} 6 \mathrm{~N}$, combined application of $6 \mathrm{Mg} / \mathrm{ha}$ of sewage sludge and $60 \mathrm{~kg} / \mathrm{ha} \mathrm{N}$; Min, mineral fertilization.

\section{Discussion}

The application of sewage sludge compost, especially to soils with low organic matter and nutrients content, has attracted great interest, being a practice that couples the fertilization management to the virtuous recycling of valuable wastes under a perspective of circular economy. If it is well documented that long-term applications of composted wastes improve soil chemical and biological properties [1,2,40], as well as affect microbial population [41], our investigation targeted the possibility to demonstrate that even short-term amendments may contribute rapidly to improve soil fertility and, consequently, crop yields and quality. In literature, different doses of sewage sludge compost were tested, ranging from 3 to $12 \mathrm{Mg} / \mathrm{ha}$, in a typical semiarid Mediterranean soil either to optimize the productivity, phenolic compounds, antioxidant activity and technological quality (protein content) of durum wheat or to maximize the morphometric and physiological growth parameters, grain yield and selected functional compounds of barley [42,43]. Regarding the productivity, the use of $12 \mathrm{Mg} / \mathrm{ha}$ of compost can effectively substitute a based-N mineral fertilization in wheat. Regarding phenolics content and antioxidant activity in wheat, further increase can be achieved by employing a combination of sewage sludge compost at the dose of $6 \mathrm{Mg} / \mathrm{ha}$ with $60 \mathrm{~kg} / \mathrm{ha} \mathrm{N}$. The phenolic compounds and the antioxidant activity of wheat meal was optimized by combined application of $6 \mathrm{Mg} / \mathrm{ha}$ sewage sludge compost and $60 \mathrm{~kg} / \mathrm{ha} \mathrm{N}$. In addition, the use of sewage sludge compost also improved both morphometric and physiological characters and yield parameters of barley by enhancing the protein content if compared to unfertilized soil.

A three-year amendment of soil pots with different amounts of sewage sludge compost from urban wastewaters affected some physicochemical and biochemical parameters related to the quality and fertility of agricultural soils and caused a shift of the bacterial community. 
One of the main drawbacks of land application with municipal biosolids is the relevant increase in soil $\mathrm{pH}$ and electrical conductivity. On the other hand, a slight increase of soil $\mathrm{pH}$ may affect trace metals sorption on soil particles and their bioavailability for plant uptake; generally, lower $\mathrm{pH}$ values lead to increased bioavailability and potential toxicity in plants [41]. Moreover, $\mathrm{pH}$ may modulate microbial structure by controlling nutrients availability and enzymatic processes that are essential to microbial metabolism; it was shown that $1 \mathrm{pH}$-unit may considerably affect bacterial community structure and composition [44].

According to other similar investigations [5,44,45], in the present study, ECe increase as the amounts of sludge increased. The effect of biosolid application on soil $\mathrm{pH}$ is in accordance with other studies [46] that demonstrated that soil $\mathrm{pH}$ increased following the nature of composts and their application rates. The $\mathrm{pH}$ and the ECe increase may be due to the mineralization of organic carbon and subsequent production of $\mathrm{OH}^{-}$by ligand exchange and to the release of basic cations $\left(\mathrm{K}^{+}, \mathrm{Ca}^{++}\right.$, $\mathrm{Mg}^{++}$) from the compost.

Organic amendments of soils with low organic matter and nutrient content, such as those from semiarid Mediterranean areas under intensive cropping systems, is a typical practice whose objective is to improve the fertility of degraded soils. According to other research [1,7], significantly higher organic carbon, total N, P and K contents validate the statement that organic wastes-based fertilizers enhance soil fertility, either directly, because they supply nutrients, or indirectly by furnishing substrates that are mineralized by soil microflora. Organic carbon added to soil with sewage sludge compost was also reported to improve bulk density, porosity, water holding capacity, and activity of aerobic bacteria [47]. Interestingly, in our case, this goal was reached after 3 years' management and even by relatively low doses of composted wastes that do not affect soil $\mathrm{pH}$ and ECe much, as well as, obviously, by higher application rates.

According to the key role of soil microorganisms, we found a significant variation of some biological properties such as enzymes activities and biomass C. Soil enzymatic activity is considered suitable parameter to detect changes in soil quality after soil disturbance by adding organic amendments because they respond to soil environmental factors and management changes much sooner than soil physicochemical properties. In particular, FDA hydrolysis is considered a suitable indicator to quantify the overall microbial activity. Microbial biomass $C$, the living portion of the soil organic matter, also represents the center of the majority of soil biological activities [48]. The increase of soil microbial biomass depends on readily metabolized $C$ brought into soil by composted waste amendments [49]. As already highlighted [50], we observed significant variations in soil microbial biomass and positive correlation with composted waste application rates. Considering the short-term treatment, it is reasonable that, in our study, the main changes were detected at higher doses of amendment. The improvement of solid phase surface properties of composted organic wastes amended soil, as clearly indicated by the higher structure stability index and water retention, increased stabilization of extracellular enzymes, according to other studies [51,52]. In addition, soil microbial community, whose size and activity are enhanced by the organic amendment, produces and releases active enzymes. In our study, this occurred for an intracellular enzyme related to oxidative processes occurring in all intact and viable microbial cells [49], as well as for two hydrolases released by microorganisms to meet their requests of energy and nutrients. It was demonstrated that the addition of mineral nitrogen to different levels of organic amendment, with the aim of changing $\mathrm{C} / \mathrm{N}$ ratios, improved microbial and enzymatic activities [53]. In this study, this was partly confirmed by the biochemical parameters investigated, but much less by the physicochemical ones; these findings lead us to hypothesize that the sewage sludge compost used here is well balanced in terms of $\mathrm{C}$ and $\mathrm{N}$ and that the key aspect to be considered to obtain the best improvement in soil fertility is the dose of amendment.

Interestingly, our results indicate that microbial biomass increases in Min treatment, too, while some enzymes activities seem not to be affected. This could be explained by the readily available mineral $\mathrm{N}$ that rapidly enhances microbial size and activities, that are not detected by specific indicators such 
as glucosidase and phosphatase. Our hypothesis is confirmed by the increase of the activity FDA hydrolase, an enzyme that quantifies, even more rapidly than microbial biomass values, the overall microbial activity; FDA hydrolase values are in fact higher in mineral as well as organic amended soil pots, in comparison to unamended control.

With the development of next-generation sequencing (NGS), new research has explored the interactions between microbial species and environmental factors. Sewage sludge compost application, improving soil fertility, nutrient content, and changing soil characteristics, could shift bacterial composition and structure, either directly or indirectly. Although $16 \mathrm{~S}$ rRNA-PCR combined with NGS strategies did not cover totally bacterial diversity, as indicated by the inability to reach plateau rarefaction curves, nonetheless a higher richness and evenness among the soil plots amended with sewage sludge compost was observed with no significant differences among application rates, when compared to the un-amended soil control and soil treated with mineral fertilization. Generally, organic amendments have been reported to be the most important tool of managing soil biodiversity [54,55]. Recent studies report that sewage sludge enhances soil microbial diversity [56] since it ameliorates the soil environment for microbial proliferation and provides macro- and micronutrients including organic matter. Our results confirm a recent hypothesis that sewage sludge compost increases the diversity and abundance of bacterial communities, because it stimulates the microbial activity [41].

The lowest diversity indices values obtained for Min soil suggest instead that mineral fertilization reduces or inhibits microbial diversity, according to a previous study which reported that long-term nitrogen-containing chemical fertilization induces soil acidification and deterioration of bacterial community [57].

The bacterial composition at the phylum level apparently does not highlight significant differences among the treatments. This is obvious because of the scale level of investigation (phylum) that very likely does not dramatically change, especially after short-term management. However, a deeper analysis of the results as evidenced by heatmap, NMDS and CCA indicates that only three years of different amendments clustered the soil pots amended with high doses of sewage sludge compost from the low dose amended and control soils. Other investigators, although after very long-term trials (26y), did not observe significant differences within the 12 most represented phyla, as a consequence of changes in fertilization regime and crop rotation, with the only exception being Cyanobacteria, that increased significantly when chemical fertilization combined with organic manure was used [58].

Among the groups responsible for such marked separation, Actinobacteria, Acidobacteria, Cyanobacteria and Bacterioides contribute the most. It has been demonstrated that some abundant bacteria phyla can be classified into two main categories, copiotrophic and oligotrophic groups, corresponding to high and low rate of nutrients, respectively; in particular, Acidobacteria are defined as slow-growing oligotrophs being more abundant in soils characterized by low organic carbon and $\mathrm{C}$ mineralization rate, while Actinobacteria, Bacterioides and Proteobacteria behave like copiotrophics [59]; manure addition increased copiotrophic taxa affiliated to Pseudomonadaceae and Cytophagaceae families, reducing some Acidobacteria groups [58]. Despite the great physiological and phylogenetic diversity existing within each group, our findings suggest that even after a short period of different fertilization plans, the overall abundance of those taxa, as expected, rapidly change as the $C$ availability increases. For other taxa that cannot be univocally assigned into the two trophic groups, it is reasonable to suggest that, if the overall abundance of such groups does not change as a function of organic carbon and nutrient content, finer levels of taxonomic resolution may bring ecological divisions of subgroups. The SIMPER analysis, even more than the heatmap, highlighted how soil samples amended differently for only three years were significantly different and the role of specific bacterial taxa (OTUs belonging to Actinobacteria, Alpha-Proteobacteria and Cyanobacteria) in this segregation. In particular, the above reported classes of bacteria are much more abundant in soil pots not amended with composted sludges. In general, despite a generally higher richness and evenness, compost-amended soil pots ( $\mathrm{C} 3$ to $\mathrm{C} 12$ ) have a lower number of sequences belonging to significant OTUs (those that contribute mostly to differentiate soils treatment) than controls. It is very likely that increasing the nutrients availability 
brings higher richness in compost amended soils, this higher richness being due to species belonging to similar taxonomic groups, those able to use readily available organic matter; on the other hand, not amended or chemically fertilized soils keep a wide number of bacterial groups targeting different nutritional strategies. This hypothesis is supported by the fact that the higher the dose of composted sludge, the lower was the number of sequences belonging to each OTUs.

It should be remembered the sewage sludge compost is not only a source of organic $\mathrm{C}$, since $\mathrm{N}$ compounds are also present. A study demonstrated an increase of copiotrophic taxa (Actinobacteria and Proteobacteria) and a concurrent decrease of Acidobacteria induced by $\mathrm{N}$ amendment [60]. Data from CCA clearly indicates that physicochemical and biological parameters change because of fertilization plan, clustering separately not amended control, mineral fertilization, and low dose of sewage sludge from the high-dose amended pots. These latter seem to influence mainly the chemical-physical parameters while control treatments affect microbial biomass and glucosidase activity. Deeper investigations are necessary to detect change within microbial composition and structure.

The effects of sewage sludge amendment observed here are dose-dependent, the higher the amount the more is the improvement of parameters related to soil fertility. It is worth noting that a concomitant use of low-rate inorganic fertilizer $(\mathrm{C} 6 \mathrm{~N})$ seems to be a balanced condition that could reduce the need of higher amounts of organic sludge and the related the drawbacks (e.g., increase of $\mathrm{pH}$ and ECe), still allowing almost optimized patterns of physicochemical and biochemical parameters related to soil fertility. The organic fertilization (fallow or manure) in combination with chemical fertilizers was also demonstrated to support the increase of copiotrophic taxa and labile C-degrading genes [57], both components responsible for enhanced nutrient cycling in soil that, in turn, improves soil productivity. The combination of organic fertilizer (e.g., organic manure) with a balanced chemical fertilization positively affecting the abundance and diversity of microbial populations (bacteria and fungi) [61].

As far as we know, few investigations have tried to demonstrate the effects of sewage sludge amendment on different soil properties, microbial activity and composition, after a short period of application. The data presented in this work could, therefore, be particularly relevant in marginal soils, such as those under semiarid conditions, where an immediate restoration of soil fertility and lower need of water, combined with the advantage derived from the reuse of a waste, may significantly improve the economy of a region. On the other hand, significant changes in bacterial composition and structure, occurring after a short time management, should be considered in order to properly balance agronomic and economic advantages with environmental concerns. In this context, our findings highlighted that, even after a short period of time, the adoption of sewage sludge compost from urban wastewater, in particular in combination with chemical fertilizer, may usefully improve physicochemical and biochemical parameters related to soil fertility, and that these parameters strictly depend on the applied dose.

We believe that our study could provide an integrated overview of the effects of the sewage sludge compost on semiarid soil, still now few investigated, as well as help to direct towards the choice of a proper dose of sewage sludge compost to apply. Considering the different composition of organic amendments and of crop/soil systems, specific trials are, therefore, strongly recommended before considering field applications of such fertilization practices.

Supplementary Materials: The following are available online at http://www.mdpi.com/2571-8789/4/3/48/s1: Figure S1: Overview of the trial during the barley growing season and the wheat growing season.

Author Contributions: For research articles with several authors, a short paragraph specifying their individual contributions must be provided. Conceptualization, C.C., G.C. and U.D.C.; methodology, M.C., G.L.; software A.L., M.C.; formal analysis, M.C., G.L.; data curation A.L., M.C., G.L.; writing-original draft preparation, C.C., M.C., G.C., A.L., U.D.C.; supervision, C.C., G.C. and U.D.C. All authors have read and agreed to the published version of the manuscript.

Funding: This research received no external funding.

Conflicts of Interest: The authors declare no conflict of interest. 


\section{References}

1. Sharma, B.; Sarkar, A.; Singh, P.; Singh, R.P. Agricultural utilization of biosolids: A review on potential effects on soil and plant grown. Waste Manag. 2017, 64, 117-132. [CrossRef] [PubMed]

2. Börjesson, G.; Kätterer, T. Soil fertility effects of repeated application of sewage sludge in two 30-year-old field experiments. Nutr. Cycl. Agroecosyst. 2018, 112, 369-385. [CrossRef]

3. Singh, R.; Singh, P.; Ibrahim, M.; Hashim, R. Land Application of sewage sludge: Physicochemical and microbial response. Rev. Environ. Contam. Toxicol. 2011, 214, 41-61. [CrossRef] [PubMed]

4. Singh, R.P.; Agrawal, M. Effect of different sewage sludge applications on growth and yield of Vigna radiata L. field crop: Metal uptake by plant. Ecol. Eng. 2010, 36, 969-972. [CrossRef]

5. Lloret, E.; Pascual, J.A.; Brodie, E.L.; Bouskill, N.J.; Insam, H.; Juárez, M.F.-D.; Goberna, M. Sewage sludge addition modifies soil microbial communities and plant performance depending on the sludge stabilization process. Appl. Soil Ecol. 2016, 101, 37-46. [CrossRef]

6. Hernández, T.; Moreno, J.I.; Costa, F. Influence of sewage sludge application on crop yields and heavy metal availability. Soil Sci. Plant. Nutr. 1991, 37, 201-210. [CrossRef]

7. Mattana, S.; Petrovičová, B.; Landi, L.; Gelsomino, A.; Cortés, P.; Ortiz, O.; Renella, G. Sewage sludge processing determines its impact on soil microbial community structure and function. Appl. Soil Ecol. 2014, 75, 150-161. [CrossRef]

8. Wang, X.; Chen, T.; Ge, Y.; Jia, Y. Studies on land application of sewage sludge and its limiting factors. J. Hazard. Mater. 2008, 160, 554-558. [CrossRef]

9. Kominko, H.; Gorazda, K.; Wzorek, Z. The possibility of organo-mineral fertilizer production from sewage Sludge. Waste Biomass Valorizat. 2017, 8, 1781-1791. [CrossRef]

10. De Corato, U. Reusing sewage sludge in agriculture: A mini-review. Agri. Res. Tech. 2020, $24,556260$. [CrossRef]

11. Singh, R.P.; Agrawal, M. Effects of sewage sludge amendment on heavy metal accumulation and consequent responses of Beta vulgaris plants. Chemosphere 2007, 67, 2229-2240. [CrossRef] [PubMed]

12. Méndez, A.; Gómez, A.; Paz-Ferreiro, J.; Gascó, G. Effects of sewage sludge biochar on plant metal availability after application to a Mediterranean soil. Chemosphere 2012, 89, 1354-1359. [CrossRef] [PubMed]

13. Redshaw, C.; Cooke, M.P.; Talbot, H.M.; McGrath, S.; Rowland, S. Low biodegradability of fluoxetine $\mathrm{HCl}$, diazepam and their human metabolites in sewage sludge-amended soil. J. Soils Sediments 2008. [CrossRef]

14. Stumpe, B.; Marschner, B. Long-term sewage sludge application and wastewater irrigation on the mineralization and sorption of $17 \beta$-estradiol and testosterone in soils. Sci. Total Environ. 2007, 374, 282-291. [CrossRef] [PubMed]

15. Cai, Q.-Y.; Mo, C.-H.; Wu, Q.-T.; Zeng, Q.-Y.; Katsoyiannis, A. Concentration and speciation of heavy metals in six different sewage sludge-composts. J. Hazard. Mater. 2007, 147, 1063-1072. [CrossRef]

16. Gerba, C.P.; Smith, J.E. Sources of pathogenic microorganisms and their fate during land application of wastes. J. Environ. Qual. 2005, 34, 42-48.

17. Wang, K.; Mao, H.; Li, X. Functional characteristics and influence factors of microbial community in sewage sludge composting with inorganic bulking agent. Bioresour. Technol. 2018, 249, 527-535. [CrossRef]

18. Masciandaro, G.; Ceccanti, B.; Garcia, C. "In situ" vermicomposting of biological sludges and impacts on soil quality. Soil Biol. Biochem. 2000, 32, 1015-1024. [CrossRef]

19. Hua, L.; Wu, W.; Liu, Y.; McBride, M.B.; Chen, Y. Reduction of nitrogen loss and Cu and Zn mobility during sludge composting with bamboo charcoal amendment. Environ. Sci. Pollut. Res. Int. 2009, 16, 1-9. [CrossRef]

20. Corrêa, R.S.; White, R.E.; Weatherley, A.J. Effect of compost treatment of sewage sludge on nitrogen behavior in two soils. Waste Manag. 2006, 26, 614-619. [CrossRef]

21. Khalil, A.I.; Hassouna, M.S.; El-Ashqar, H.M.A.; Fawzi, M. Changes in physical, chemical and microbial parameters during the composting of municipal sewage sludge. World J. Microbiol. Biotechnol. 2011, 27, 2359-2369. [CrossRef]

22. Bertoncini, E.I.; D'Orazio, V.; Senesi, N.; Mattiazzo, M.E. Effects of sewage sludge amendment on the properties of two Brazilian oxisols and their humic acids. Bioresour. Technol. 2008, 99, 4972-4979. [CrossRef] [PubMed]

23. Singh, R.P.; Agrawal, M. Potential benefits and risks of land application of sewage sludge. Waste Manag. 2008, 28, 347-358. [CrossRef] [PubMed] 
24. Hossain, M.Z.; Von Fragstein, P.; Von Niemsdorff, P.; Hes, J. Effect of different organic wastes on soil propertie S and plant growth and yield: A review. Sci. Agric. Bohem. 2017, 48, 224-237. [CrossRef]

25. Srivastava, V.; Araujo, A.S.F.D.; Vaish, B.; Bartelt-Hunt, S.; Singh, P.; Singh, R.P. Biological response of using municipal solid waste compost in agriculture as fertilizer supplement. Rev. Environ. Sci. Biotechnol. 2016, 15, 677-696. [CrossRef]

26. Delibacak, S.; Voronïna, L.; Morachevskaya, E. Use of sewage sludge in agricultural soils: Useful or harmful. Eurasian J. Soil Sci. 2020, 9, 126-139. [CrossRef]

27. Marschner, P.; Kandeler, E.; Marschner, B. Structure and function of the soil microbial community in a long-term fertilizer experiment. Soil Biol. Biochem. 2003, 35, 453-461. [CrossRef]

28. Italian Legislative Decree no. 217 of April 29th 2006. Revisione della Disciplina in Materia di 630 Fertilizzanti; Ordinary Supplement no. 152; Gazzetta Ufficiale della Repubblica Italiana: Rome, Italy, 2006.

29. Violante, P. Chemical Methods of Soil Analysis; Franco Angeli Press: Milan, Italy, 2000.

30. Rathje Jackson, M.L. Soil Chemical Analysis; Prentice Hall Inc.: Englewood Cliffs, NJ, USA, 1958; pp. $251-252$.

31. Hénin, S.; Monnier, G. Evaluation de la stabilité de la structure du sol. In Proceedings of the 6th Congrès International Science du Sol, Paris, France, 6-11 February 1956.

32. Alef, K.; Nannipieri, P. Methods in Applied Soil Microbiology and Biochemistry; Academic Press: Cambridge, MA, USA, 1995.

33. Green, V.S.; Stott, D.E.; Diack, M. Assay for fluorescein diacetate hydrolytic activity: Optimization for soil samples. Soil Biol. Biochem. 2006, 38, 693-701. [CrossRef]

34. Vance, E.D.; Brookes, P.C.; Jenkinson, D.S. An extraction method for measuring soil microbial biomass C. Soil Biol. Biochem. 1987, 19, 703-707. [CrossRef]

35. Klindworth, A.; Pruesse, E.; Schweer, T.; Peplies, J.; Quast, C.; Horn, M.; Glöckner, F.O. Evaluation of general $16 \mathrm{~S}$ ribosomal RNA gene PCR primers for classical and next-generation sequencing-based diversity studies. Nucl. Acids Res. 2013, 41, e1. [CrossRef]

36. Schloss, P.D.; Westcott, S.L.; Ryabin, T.; Hall, J.R.; Hartmann, M.; Hollister, E.B.; Lesniewski, R.A.; Oakley, B.B.; Parks, D.H.; Robinson, C.J.; et al. Introducing mothur: Open-source, platform-independent, community-supported software for describing and comparing microbial communities. Appl. Environ. Microbiol. 2009, 75, 7537-7541. [CrossRef] [PubMed]

37. Quast, C.; Pruesse, E.; Yilmaz, P.; Gerken, J.; Schweer, T.; Yarza, P.; Peplies, J.; Glöckner, F.O. The SILVA ribosomal RNA gene database project: Improved data processing and web-based tools. Nucl. Acids Res. 2013, 41, D590-D596. [CrossRef] [PubMed]

38. Caraux, G.; Pinloche, S. PermutMatrix: A graphical environment to arrange gene expression profiles in optimal linear order. Bioinforma. Oxf. Engl. 2005, 21, 1280-1281. [CrossRef] [PubMed]

39. Hammer, O.; Harper, D.A.T.; Ryan, P.D. PAST: Paleontological statistics software package for education and data analysis. Palaeontol. Electron. 2001, 4, 9.

40. Mehrotra, A.; Kundu, K.; Sreekrishnan, T.R. Decontamination of heavy metal laden sewage sludge with simultaneous solids reduction using thermophilic sulfur and ferrous oxidizing species. J. Environ. Manag. 2016, 167, 228-235. [CrossRef]

41. Bai, Y.; Mei, L.; Zuo, W.; Zhang, Y.; Gu, C.; Shan, Y.; Hu, J.; Dai, Q. Response of bacterial communities in coastal mudflat saline soil to sewage sludge amendment. Appl. Soil Ecol. 2019, 144, 107-111. [CrossRef]

42. Pasqualone, A.; Delvecchio, L.N.; Lacolla, G.; Piarulli, L.; Simeone, R.; Cucci, G. Effect of composted sewage sludge on durum wheat: Productivity, phenolic compounds, antioxidant activity, and technological quality. J. Food Agric. Amp Environ. 2014, 12, 276-280.

43. Pasqualone, A.; Summo, C.; Centomani, I.; Lacolla, G.; Caranfa, G.; Cucci, G. Effect of composted sewage sludge on morpho-physiological growth parameters, grain yield and selected functional compounds of barley. J. Sci. Food Agric. 2017, 97, 1502-1508. [CrossRef]

44. Fierer, N.; Jackson, R.B. The diversity and biogeography of soil bacterial communities. Proc. Natl. Acad. Sci. USA 2006, 103, 626-631. [CrossRef]

45. Walter, I.; Martínez, F.; Cuevas, G. Plant and Soil Responses to the Application of Composted MSW in a Degraded, Semiarid Shrubland in Central Spain. Compost Sci. Util. 2013, 14, 147-154. [CrossRef]

46. Ouni, Y.; Lakhdar, A.; Scelza, R.; Scotti, R.; Abdelly, C.; Barhoumi, Z.; Rao, M.A. Effects of two composts and two grasses on microbial biomass and biological activity in a salt-affected soil. Ecol. Eng. 2013, 60, 363-369. [CrossRef] 
47. Ramulu, U.S.S. Reuse of Municipal Sewage and Sludge in Agriculture; Scientific Publishers: Rajasthan, India, 2001; ISBN 978-81-7233-254-9.

48. De Corato, U. Disease-suppressive compost enhances natural soil suppressiveness against soil-borne plant pathogens: A critical review. Rhizosphere 2020, 13, 100192. [CrossRef]

49. Tejada, M.; Garcia, C.; Gonzalez, J.L.; Hernandez, M.T. Organic amendment based on fresh and composted beet vinasse. Soil Sci. Soc. Am. J. 2006, 70, 900-908. [CrossRef]

50. Bettiol, W.; Ghini, R. Impacts of sewage sludge in tropical soil: A case study in Brazil. Appl. Environ. Soil Sci. 2011, 2011, 1-11. [CrossRef]

51. García-Ruiz, R.; Ochoa, V.; Hinojosa, M.B.; Carreira, J.A. Suitability of enzyme activities for the monitoring of soil quality improvement in organic agricultural systems. Soil Biol. Biochem. 2008, 40, 2137-2145. [CrossRef]

52. Torri, S.I.; Corrêa, R.S.; Renella, G. Soil carbon sequestration resulting from biosolids application. Appl. Environ. Soil Sci. 2014, 2014, 1-9. [CrossRef]

53. Kızllkaya, R.; Bayrakl1, B. Effects of N-enriched sewage sludge on soil enzyme activities. Appl. Soil Ecol. 2005, 30, 192-202. [CrossRef]

54. Brussaard, L.; de Ruiter, P.C.; Brown, G.G. Soil biodiversity for agricultural sustainability. Agric. Ecosyst. Environ. 2007, 121, 233-244. [CrossRef]

55. Lavecchia, A.; Curci, M.; Jangid, K.; Whitman, W.B.; Ricciuti, P.; Pascazio, S.; Crecchio, C. Microbial 16S gene-based composition of a sorghum cropped rhizosphere soil under different fertilization managements. Biol. Fertil. Soils 2015, 51, 661-672. [CrossRef]

56. Al-Kindi, S.; Abed, R.M.M. Effect of biostimulation using sewage sludge, soybean meal, and wheat straw on oil degradation and bacterial community composition in a contaminated desert soil. Front. Microbiol. 2016, 7. [CrossRef]

57. Xun, W.; Zhao, J.; Xue, C.; Zhang, G.; Ran, W.; Wang, B.; Shen, Q.; Zhang, R. Significant alteration of soil bacterial communities and organic carbon decomposition by different long-term fertilization management conditions of extremely low-productivity arable soil in South China. Environ. Microbiol. 2016, 18, 1907-1917. [CrossRef] [PubMed]

58. Ai, C.; Zhang, S.; Zhang, X.; Guo, D.; Zhou, W.; Huang, S. Distinct responses of soil bacterial and fungal communities to changes in fertilization regime and crop rotation. Geoderma 2018, 319, 156-166. [CrossRef]

59. Fierer, N.; Bradford, M.A.; Jackson, R.B. Toward an ecological classification of soil bacteria. Ecology 2007, 88, 1354-1364. [CrossRef] [PubMed]

60. Männistö, M.; Ganzert, L.; Tiirola, M.; Häggblom, M.M.; Stark, S. Do shifts in life strategies explain microbial community responses to increasing nitrogen in tundra soil? Soil Biol. Biochem. 2016, 96, 216-228. [CrossRef]

61. Pan, H.; Chen, M.; Feng, H.; Wei, M.; Song, F.; Lou, Y.; Cui, X.; Wang, H.; Zhuge, Y. Organic and inorganic fertilizers respectively drive bacterial and fungal community compositions in a fluvo-aquic soil in northern China. Soil Tillage Res. 2020, 198, 104540. [CrossRef] 